\title{
Uji fotokatalisis reduksi benzaldehida menggunakan titanium dioksida hasil sintesis
}

\section{OJS}

\author{
Diana Rakhmawaty Eddy*, Sanidya Saraswati B, Rustaman \\ Departemen Kimia, FMIPA, Universitas Padjadjaran, Bandung \\ *Email: diana.rahmawati@unpad.ac.id
}

\begin{abstract}
ABSTRAK
Sintesis senyawa organik pada umumnya membutuhkan pelarut yang cukup berbahaya karena bersifat toksik dan karsinogenik. Saat ini terdapat cara untuk sintesis senyawa organik baru yang tidak menggunakan pelarut berbahaya yaitu menggunakan salah satu semikonduktor sebagai fotokatalis yaitu titanium dioksida. Titanium dioksida $\left(\mathrm{TiO}_{2}\right)$ digunakan sebagai fotokatalis yang ramah lingkungan karena bersifat lembam, stabilitas termalnya baik, non-toksik, tahan pada suhu tinggi dan aktifitas katalitiknya yang cukup baik. Tujuan dari penelitian ini adalah untuk mengetahui kemampuan aktivitas fotokatalitik $\mathrm{TiO}_{2}$ hasil sintesis dengan variasi $\mathrm{pH}$ dibandingkan dengan $\mathrm{TiO}_{2} \mathrm{P} 25$ Degussa dalam mereduksi senyawa organik yaitu benzaldehida. Uji aktivitas fotokatalitik dilakukan terhadap benzaldehida, lalu diuji identifikasi gugus fungsi yaitu uji Ritter dan uji Lucas untuk mengidentifikasi produk yang dihasilkan, didapatkan $\mathrm{TiO}_{2} \mathrm{P} 25$ Degussa dan $\mathrm{TiO}_{2} \mathrm{pH} 3$ dengan aktivitas fotokatalitik paling baik dalam mereduksi benzaldehida.
\end{abstract}

Kata kunci: Fotokatalis; titanium dioksida; benzaldehida.

\section{PENDAHULUAN}

Titanium dioksida banyak digunakan sebagai fotokatalis karena bersifat lembam, stabilitas termalnya baik, non-toksik, tahan pada suhu tinggi dan aktifitas katalitiknya cukup baik (Sudirman dkk., 2015). Saat ini titanium dioksida juga mulai digunakan sebagai katalis yang ramah lingkungan dalam proses sintesis senyawa organik (Hoffman, 2015). Sintesis senyawa organik pada umumnya melewati tahapan yang cukup panjang dan menggunakan pelarut yang berbahaya. Pelarut yang biasa digunakan pada sintesis senyawa organik pada umumnya adalah tetrahidrofuran (THF) atau dietil eter, namun pelarut THF cukup berbahaya karena cenderung akan membentuk peroksida jika disimpan dalam udara sehingga mudah meledak dan dietil eter yang bersifat toksik (Luder \& Ein-Eli, 2014). Jika menggunakan titanium dioksida sebagai fotokatalis, muatan-muatan yang terdapat pada senyawa organik yang akan disintesis akan mengalami reduksi dan oksidasi pada pita valensi, yang dapat mengurai air $\left(\mathrm{H}_{2} \mathrm{O}\right)$ menjadi gas $\mathrm{H}_{2}$ dan gas $\mathrm{O}_{2}$ dan tidak menggunakan pelarut berbahaya sehingga lebih ramah lingkungan (Hoffman, 2015).

Berdasarkan hasil studi (Hoffman, 2015) titanium dioksida nanopartikel P25 Degussa dapat digunakan sebagai fotokatalis untuk mereduksi benzaldehida. Pada penelitian ini digunakan titanium dioksida hasil sintesis dengan variasi $\mathrm{pH}$ dan dilakukan uji produk hasil reduksi benzaldehida yang merupakan golongan alkohol primer dengan uji identifikasi gugus fungsi yaitu uji Ritter dan uji Lucas.

\section{METODE PENELITIAN}

\section{Bahan}

Bahan yang digunakan dalam penelitian ini adalah asam asetat glasial $\left(\mathrm{CH}_{3} \mathrm{COOH}, 100 \%\right.$, Merck), asam klorida p.a. (HCl, 37\%, Merck), benzaldehida $\left(\mathrm{C}_{6} \mathrm{H}_{5} \mathrm{CHO}\right.$, Merck), benzil alkohol p.a., kalium permanganat $\left(\mathrm{KMnO}_{4}\right.$, crystal extra pure, Merck), seng klorida $\left(\mathrm{ZnCl}_{2}\right)$, titanium dioksida P25 Degussa, titanium dioksida hasil sintesis. 


\section{Metode}

Prosedur kerja penelitian meliputi sintesis dan karakterisasi fotokatalis titanium dioksida yang telah kami kerjakan sebelumnya, serta uji fotokatalitik pada benzaldehida yang merujuk pada Hoffman tahun 2015.

\section{Uji aktivitas fotokatalitik $\mathrm{TiO}_{2}$ terhadap benzaldehida}

Sebanyak $10 \mathrm{~mL}$ benzaldehida dan $10 \mathrm{~mL}$ suspensi $\mathrm{TiO}_{2}$ hasil sintesis $\mathrm{pH} 1$ dalam akuades dimasukkan ke dalam tabung kuarsa dan ditutup rapat lalu dialirkan dengan gas nitrogen selama 5 menit. Tabung kuarsa tersebut dimasukkan ke dalam fotoreaktor dan diiradiasi dengan lampu $\mathrm{Hg}$ selama 4 jam. Setelah 4 jam sebanyak $2 \mathrm{~mL}$ sampel diambil lalu dilakukan penyaringan dengan syringe membrane. Perlakuan yang sama dilakukan pada $\mathrm{TiO}_{2} \mathrm{pH} 2, \mathrm{pH} 3$, dan $\mathrm{P} 25$ Degussa.

\section{Uji Ritter}

Larutan hasil radiasi dipipet ke dalam tabung reaksi, ditambahkan asam asetat glasial lalu diaduk, ditambahkan kalium permanganat secara perlahan. Jika larutan berubah menjadi warna ungu dan memudar maka menandakan adanya alkohol primer atau sekunder, jika larutan tidak berubah menjadi warna ungu maka menandakan adanya alkohol tersier.

\section{Uji Lucas}

Larutan hasil radiasi dipipet dan dimasukkan ke dalam tabung reaksi, ditambahkan asam klorida lalu diaduk, ditambahkan seng klorida secara perlahan. Jika larutan berubah menjadi keruh dalam waktu yang lama maka menandakan adanya alkohol tersier, sedangkan jika larutan berubah menjadi warna keruh dalam waktu relatif tidak lama maka menandakan adanya alkohol sekunder, dan jika larutan tidak berubah warna maka menandakan adanya alkohol primer.

\section{HASIL DAN PEMBAHASAN}

\section{Karakterisasi Titanium Dioksida}

$\mathrm{TiO}_{2}$ hasil sintesis telah kami laporkan sebelumnya (Eddy dkk, 2018), bahwa hasil difraktogram XRD menunjukkan puncak yang muncul pada sekitar $25^{\circ}, 37^{\circ}$, dan $54^{\circ}$ yang merupakan puncak khas $\mathrm{TiO}_{2}$ dengan fase anatase sehingga menandakan hasil sintesis tersebut sesuai dengan standar. $\mathrm{TiO}_{2}$ dengan nilai pH 1 memiliki puncak tertinggi pada $25^{\circ}$ dibandingkan dengan titanium dioksida hasil sintesis nilai $\mathrm{pH} 2$ dan $\mathrm{pH} 3$ memiliki puncak yang paling rendah. Hal ini menandakan bahwa semakin asam larutan $\mathrm{TiO}_{2}$ maka semakin baik untuk membentuk kristal dengan fase anatase. Semakin tinggi intensitas puncak pada difraktogram XRD menunjukkan bahwa hasil sintesis tersebut memiliki kristalinitas yang tinggi (Eddy dkk., 2017).

Dari Tabel 1 dapat terlihat bahwa $\mathrm{pH}$ berpengaruh pada ukuran partikel titanium dioksida, terlihat bahwa titanium dioksida hasil sintesis dengan nilai $\mathrm{pH} 1$ memiliki ukuran partikel yang paling besar diantara ketiganya. Sehingga dapat disimpulkan bahwa semakin besar nilai $\mathrm{pH}$ maka akan semakin kecil ukuran partikel $\mathrm{TiO}_{2}$, hal ini disebabkan nilai $\mathrm{pH}$ yang semakin rendah akan lebih memacu peningkatan jumlah kelompok partikel dengan ukuran yang lebih besar dan sesuai dengan hasil penelitian yang dilakukan oleh Dewi dkk, 2015.

Tabel 1. Ukuran partikel $\mathrm{TiO}_{2}$ pada $\mathrm{pH}$ berbeda menggunakan pelarut etanol dan air deionisasi

\begin{tabular}{cc}
\hline \multirow{2}{*}{ Sampel } & Ukuran partikel \\
\cline { 2 - 2 } & $/ \mu \mathrm{m}$ \\
\hline $\mathrm{TiO}_{2}$ pH 1 & 26,36 \\
$\mathrm{TiO}_{2}$ pH 2 & 22,75 \\
$\mathrm{TiO}_{2}$ pH 3 & 13,91 \\
\hline
\end{tabular}

Gambar 1 menunjukkan bahwa hasil sintesis $\mathrm{TiO}_{2}$ memiliki morfologi yang tidak homogen yang didukung oleh data hasil analisis menggunakan PSA, namun Gambar 1(d) yaitu $\mathrm{TiO}_{2}$ dengan nilai pH 3 menunjukkan hasil yang paling homogen diantara yang lainnya. Hal ini dapat disebabkan proses pembentukan partikel yang tidak sempurna pada tahap hidrolisis, dapat juga disebabkan penggerusan serbuk yang tidak sempurna karena menggunakan mortar yang permukaannya tidak rata. Sesuai dengan hasil PSA bahwa pada hasil sintesis serbuk $\mathrm{TiO}_{2}$ terjadi aglomerisasi partikel primer, sehingga ukurannya tidak homogen. 


\section{Uji aktivitas fotokatalis $\mathrm{TiO}_{2}$}

Uji aktivitas ini dilakukan untuk mengetahui keberhasilan fotokatalis $\mathrm{TiO}_{2}$ hasil sintesis yang dibandingkan dengan $\mathrm{TiO}_{2}$ P25 Degussa terhadap benzaldehida. Benzaldehida dipilih karena saat direduksi dapat menghasilkan produk alkohol yang banyak digunakan pada sintesis senyawa organik.
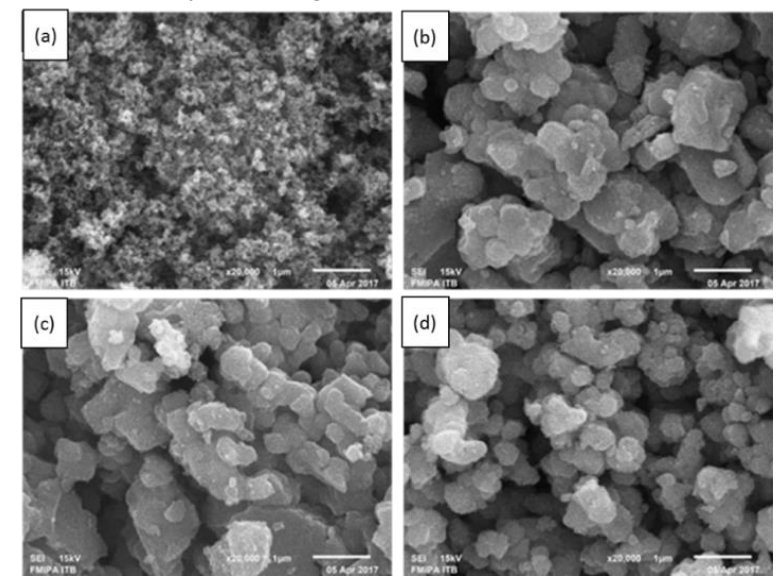

Gambar 1. Hasil analisis menggunakan SEM (a) $\mathrm{TiO}_{2}$ P25 Degussa; (b) $\mathrm{TiO}_{2} \mathrm{pH} \mathrm{1;}$ (c) $\mathrm{TiO}_{2} \mathrm{pH} 2$; (d) $\mathrm{TiO}_{2} \mathrm{pH} 3$ dengan perbesaran 20.000 kali.

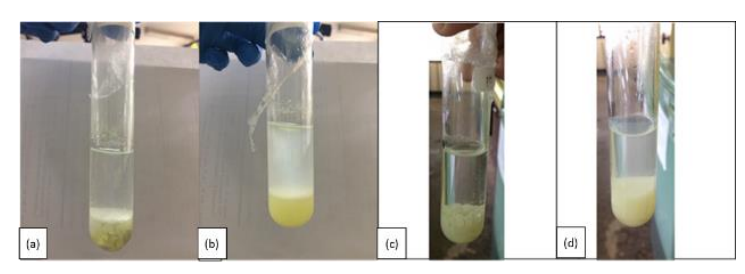

Gambar 2. Hasil uji aktivitas fotokatalis $\mathrm{TiO}_{2}$ (a) $\mathrm{pH} \mathrm{1;} \mathrm{(b)} \mathrm{pH} 2$; (c) $\mathrm{pH} 3$; (d) $\mathrm{P} 25$ Degussa.

Gambar 2 terlihat setelah dialirkan gas nitrogen, campuran benzaldehida dan $\mathrm{TiO}_{2}$ di dalam tabung kuarsa diiradiasi sambil diaduk menggunakan pengaduk magnet selama 4 jam dengan lampu merkuri. Untuk mengetahui apakah fotokatalis $\mathrm{TiO}_{2}$ bekerja maka dilakukan uji identifikasi gugus fungsi untuk mengetahui apakah benzaldehida tereduksi menjadi benzil alkohol. Benzil alkohol merupakan golongan alkohol primer, untuk mengetahui apakah terdapat alkohol primer maka dilakukan uji Ritter dan uji Lucas. Uji Ritter dan uji Lucas berfungsi untuk membedakan alkohol primer, alkohol

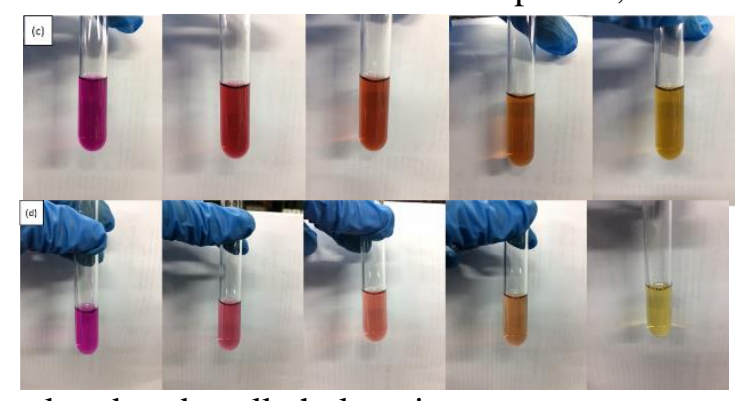

sekunder, dan alkohol tersier.

Gambar 3. Perubahan warna uji Ritter menggunakan $\mathrm{TiO}_{2}$ (a) pH 3 dan (b) P25 Degussa.

Hasil uji fotokatalitik pada $\mathrm{TiO}_{2}$ hasil sintesis dengan nilai $\mathrm{pH} 3$ dan P25 Degussa menunjukkan adanya alkohol primer karena warna ungu pada larutan yang memudar yang ditunjukkan pada Gambar 3. Persamaan reaksi pada uji Ritter ditunjukkan pada Gambar 4.

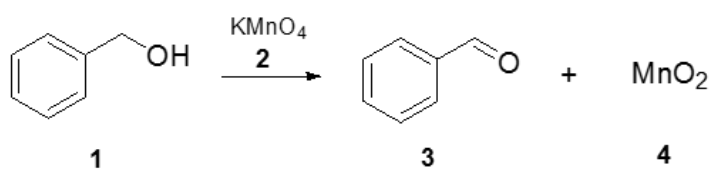

Gambar 4. Persamaan reaksi uji ritter

Saat sampel terdapat alkohol primer 1 lalu ditambahkan kalium permanganat $\mathbf{2}$ maka alkohol tersier akan akan teroksidasi menjadi aldehida 3 sedangkan kalium permanganat akan tereduksi menjadi mangan dioksida 4 yang memberikan warna cokelat yang dicatat waktu perubahan warnanya menggunakan stopwatch untuk mengetahui $\mathrm{TiO}_{2}$ dengan nilai $\mathrm{pH}$ mana yang dapat mereduksi benzaldehida paling baik yang ditunjukkan pada Tabel 2.

Tabel 2. Waktu perubahan warna pada uji Ritter

\begin{tabular}{cc}
\hline Sampel & $\begin{array}{c}\text { Waktu perubahan } \\
\text { warna/detik }\end{array}$ \\
\hline $\mathrm{TiO}_{2}$ pH 1 & 155 \\
$\mathrm{TiO}_{2}$ pH 2 & 168 \\
$\mathrm{TiO}_{2}$ pH 3 & 141 \\
$\mathrm{TiO}_{2} \mathrm{P}_{2}$ 5 Degussa & 132 \\
\hline
\end{tabular}


Hal ini menunjukkan bahwa $\mathrm{TiO}_{2}$ dengan pH 3 dapat mereduksi benzaldehida paling baik dibandingkan hasil sintesis yang lain. Semakin cepat waktu perubahan warna pada uji Ritter menandakan semakin banyak benzil alkohol yang terbentuk. Namun $\mathrm{TiO}_{2}$ hasil sintesis tidak mereduksi lebih baik dibandingkan dengan $\mathrm{TiO}_{2}$ P25 Degussa menurut Pratama pada tahun 2010, hal ini bisa disebabkan ukuran partikel dari hasil sintesis masih berukuran mikron sedangkan $\mathrm{TiO}_{2}$ P25 Degussa sudah berukuran nano sehingga luas permukaan untuk mereduksi benzaldehida lebih baik dibandingkan dengan hasil sintesis dan dapat disebabkan kristal $\mathrm{TiO}_{2}$ hasil sintesis kurang homogen jika dibandingkan dengan $\mathrm{TiO}_{2}$ P25 Degussa.

Uji Ritter dapat membedakan alkohol tersier namun tidak dapat membedakan alkohol primer dan alkohol sekunder, maka dari itu dilakukan uji Lucas yang dapat membedakan alkohol primer, alkohol sekunder, dan alkohol tersier lebih akurat (Wade, 2013). Hasil iradiasi dipipet lalu dimasukkan ke dalam tabung reaksi dan ditambahkan reagen Lucas yang terdiri atas asam klorida dan seng klorida. Asam klorida berfungsi sebagai katalis asam dan $\mathrm{ZnCl}_{2}$ berfungsi sebagai asam lewis yang akan membuat larutan semakin asam. Menurut Wade tahun 2013 saat pada sampel terdapat alkohol tersier maka larutan akan berubah menjadi 2 fase dalam waktu kurang dari 1 menit, karena saat bereaksi akan terbentuk karbokation yang sangat stabil sehingga akan bereaksi sangat cepat.

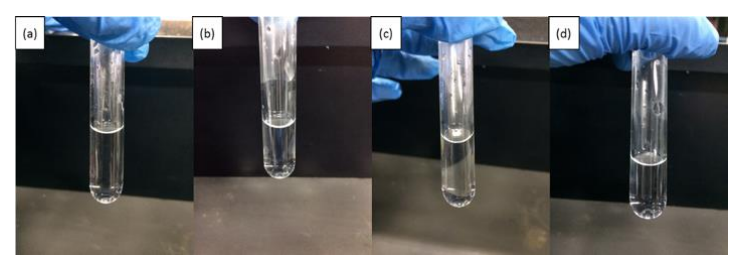

Gambar 5. Iradiasi $\mathrm{TiO}_{2}$ menggunakan uji Lucas (a) $\mathrm{pH} 1$; (b) $\mathrm{pH} 2$; (c) $\mathrm{pH} 3$; (d) P25 Degussa.

Saat pada sampel terdapat alkohol sekunder maka akan terbentuk 2 fase setelah 1 sampai 5 menit karena saat bereaksi akan menghasilkan karbokation yang kurang stabil dibandingkan dengan alkohol tersier dan saat pada sampel terdapat alkohol primer larutan tidak akan menjadi 2 fase dalam waktu yang singkat. Waktu yang dibutuhkan adalah 10 menit sampai beberapa hari hal ini disebabkan saat alkohol primer bereaksi tidak memungkinkan untuk membentuk karbokation yang stabil. Pada hasil uji fotokatalitik terhadap benzaldehida menggunakan $\mathrm{TiO}_{2}$ P25 Degussa, pH 1, pH 2, dan $\mathrm{pH} 3$ larutan tidak membentuk 2 fase yang ditunjukkan pada Gambar 5.

Hal ini menandakan bahwa pada larutan terdapat alkohol primer karena saat sampel ditambahkan $\mathrm{HCl}$ dan $\mathrm{ZnCl}_{2}$ larutan tidak membentuk 2 fase dan tetap tidak satu fase. Reaksi pada uji Lucas jika terdapat alkohol sekunder ditunjukkan pada Gambar 6, menurut Wade tahun 2013 saat alkohol sekunder 5 bereaksi dengan seng klorida $\mathbf{6}$ akan menghasilkan kompleks alkohol- seng klorida 7 yang akan lepas dan membentuk karbokation 8 yang stabil dibandingkan dengan karbokation pada alkohol primer lalu akan bereaksi dengan ion $\mathrm{Cl}$ dan akan membentuk alkil halida 9 yang bersifat non polar sehingga tidak larut dengan air dan membentuk 2 fase.

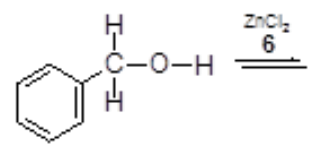

5

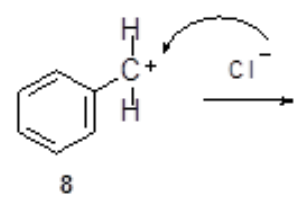

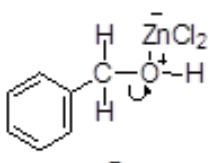

7

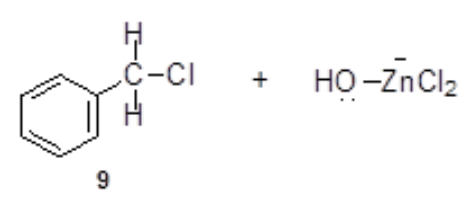

Gambar 6. Mekanisme reaksi uji Lucas pada alkohol sekunder.

Sedangkan saat pada sampel terdapat alkohol primer, maka alkohol primer tidak dapat membentuk karbokation yang stabil sehingga alkohol primer $\mathbf{1 0}$ akan bereaksi secara serentak dalam jangka waktu yang lebih lama dan akan mengalami keadaan transisi 11 yang ditunjukkan pada Gambar 7.

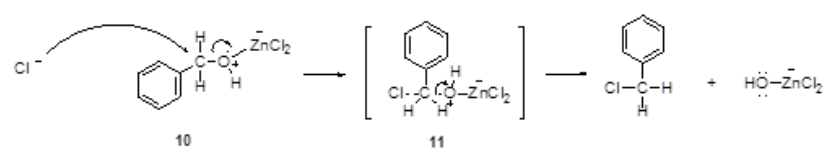

Gambar 7. Mekanisme reaksi uji Lucas pada alkohol primer. 
Uji Ritter dan uji Lucas dilakukan juga terhadap benzil alkohol p.a. sebagai standar, hasil pada benzil alkohol ditunjukkan pada Gambar 8. Hal ini membuktikan bahwa produk hasil iradiasi memiliki perubahan warna yang sama dengan benzil alkohol p.a. pada uji Ritter yang berubah warna dengan waktu 57 detik, dan tidak terbentuk 2 fase pada uji Lucas.

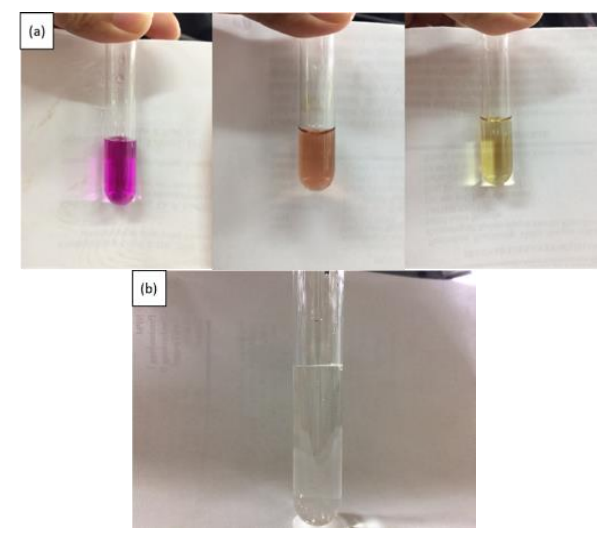

Gambar 8. Hasil (a) uji Ritter; (b) uji Lucas pada benzil alkohol p.a.

Untuk membuktikan apakah fotokatalis ini bekerja atau tidak jika digunakan tanpa sinar, maka dilakukan uji fotokatalitik tanpa menggunakan sinar UV, maka dilakukan uji fotokatalitik dengan prosedur yang sama. Sampel yang digunakan adalah $\mathrm{TiO}_{2} \mathrm{pH} \quad 3$ sebagai representatif dan $\mathrm{TiO}_{2} \mathrm{P} 25$ sebagai pembanding. Sampel yang telah diradiasi selama 4 jam dianalisis dengan uji Ritter. Setelah diuji, sampel yang diuji tanpa menggunakan sinar UV tidak menunjukkan perubahan apapun pada uji Ritter yang ditandai dengan warna ungu pada larutan yang tidak memudar Gambar 9.

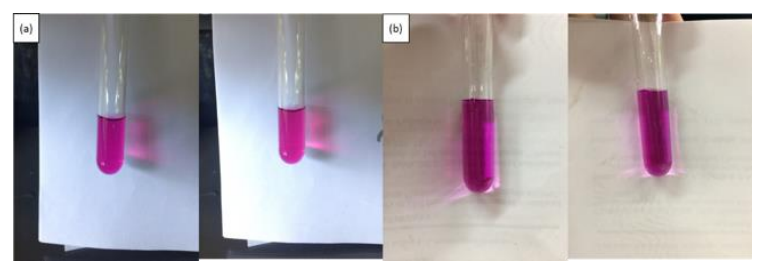

Gambar 9. Hasil uji Ritter pada $\mathrm{TiO}_{2}$ (a) $\mathrm{pH} 3$; (b) P25 Degussa tanpa menggunakan sinar UV
Hal ini menandakan bahwa fotokatalis $\mathrm{TiO}_{2}$ hasil sintesis dan $\mathrm{TiO}_{2} \mathrm{P} 25$ Degussa tidak bekerja tanpa menggunakan sinar UV, sehingga dapat dibuktikan bahwa hasil sintesis $\mathrm{TiO}_{2}$ merupakan fotokatalis.

\section{KESIMPULAN}

Titanium dioksida hasil sintesis pada $\mathrm{pH} 3$ menghasilkan bentuk kristal anatase dengan ukuran partikel terkecil sebesar 13,91 $\mu \mathrm{m}$, serta memiliki aktivitas fotokatalitik yang paling baik dibandingkan dengan hasil sintesis lain yang ditunjukkan oleh uji Ritter larutan berubah warna dengan waktu 141 detik.

\section{DAFTAR PUSTAKA}

Dewi, L. P., Sembiring, S., dan Simanjuntak, W., 2015. Pengaruh $\mathrm{pH}$ Terhadap Distribusi Ukuran Partikel Alumina yang ihasilkan Secara Elektrokimia. Jurnal Teori dan Aplikasi Fisika. 3, 75-81.

Eddy, D. R., Aldelina, A., dan Noviyanti, A. R. 2017. Perbandingan Nanokristal Titanium Dioksida Metode Hidrotermal dengan P25 Degussa untuk Uji Fotokatalitik Arsenik. Jurnal Pendidikan Kimia. 9, 249-253.

Eddy, D.R. dan Rustaman, 2018. Conference proceeding BICSE - 2017, ISBN: 978602-8043-84-7, pp 179-182.

Hoffman, N., 2015. Photocatalyst with $\mathrm{TiO}_{2}$ Applied to Organic Synthesis. Journal Compilation. 10, 1-19.

Luder, D., dan Ein-Eli, Y., 2014. Electrochemical Grignard Reagent Synthesis for Ionic-Liquid-Based Magnesium-Air Batteries. Journal Electrochemistry. 1, 1319-1326.

Sudirman, Riska, A., Subaer, dan Jasruddin., 2015. Sintesis dan Karakterisasi Nanopartikel Fotokatalis $\mathrm{TiO}_{2} /$ Karbon Aktif Sebagai Adsorben Limbah Organik. Pertemuan Ilmiah XXIX HFI Jateng \& Diy. Yogyakarta. pp 347-351.

Wade, L. 2013. Organic Chemistry 8th Edition. New York: Person Prentice Hall. 